DOI: $10.25140 / 2411-5363-2021-3(25)-213-219$

UDC 621.941-229.3:621.822.172

\author{
Marek Sukop ${ }^{1}$, Maksym Grytsiv ${ }^{2}$, Karol Krabáč $\breve{c}^{3}$ \\ ${ }^{1}$ Professor, Faculty of Mechanical Engineering, Department of Production Systems and Robotics \\ Technical University of Kosice (Kosice, Slovakia) \\ E-mail: marek.sukop@tuke.sk. ORCID: https://orcid.org/0000-0001-7987-3557 \\ ${ }^{2} \mathrm{PhD}$ Student, Faculty of Mechanical Engineering, Department of Production Systems and Robotics \\ Technical University of Kosice (Kosice, Slovakia) \\ E-mail: maksym.grytsiv@tuke.sk. ORCID: https://orcid.org/0000-0002-9412-085X \\ ${ }^{3}$ Ing. Student, Faculty of Mechanical Engineering, Department of Production Systems and Robotics \\ Technical University of Kosice (Kosice, Slovakia) \\ E-mail: karol.kabac@student.tuke.sk
}

\title{
SIMPLE SPEED MEASUREMENT IN SPORT BASED ON ULTRASOUND
}

The intention of our solution mentioned in the article was to create a simple device capable of measuring speed of a moving object. For various sports, such equipment is necessary during athletes' performance testing to determine progress. The designed device based on the ultrasonic sensor HC-SR04 in conjunction with Arduino is simple and inexpensive. The most important task in the implementation was to solve the synchronization between the measuring modules [1]. The nRF24L01 communication modules were used to synchronize the modules.

Keywords: sport; ultrasound; ultrasonic sensor; speed measurement.

Fig.: 9. References: 4.

Urgency of the research. IIn the training process of amateur and professional sports, an analysis of increasing performance is needed. This can be done by objectively measuring some of an athlete's abilities (needed for sport). One of the important abilities is the maximum running speed of an athlete. This ability is also needed in most team sports.

Target setting and Actual scientific researchers and issues analysis. As part of our solution, we first proposed a speed measurement method using the radar method. In this solution, only one ultrasonic sensor would be used, the position of which would be as parallel as possible to the direction of movement of the measured object [1]. The movement of measured object would be towards the sensor. To determine the speed, we would evaluate at least two distances of the object from the radar. Here, however, there was a problem with sensing the distance of a dressed person, where the signal was too attenuated. This signal could not be processed. Therefore, we decided to implement the method of two points through which the measured object must pass.

The statement of basic materials. The measurement method is based on the principle of measuring speed in a section given by two points. The velocity is calculated as a derivative of the length of the section over time.

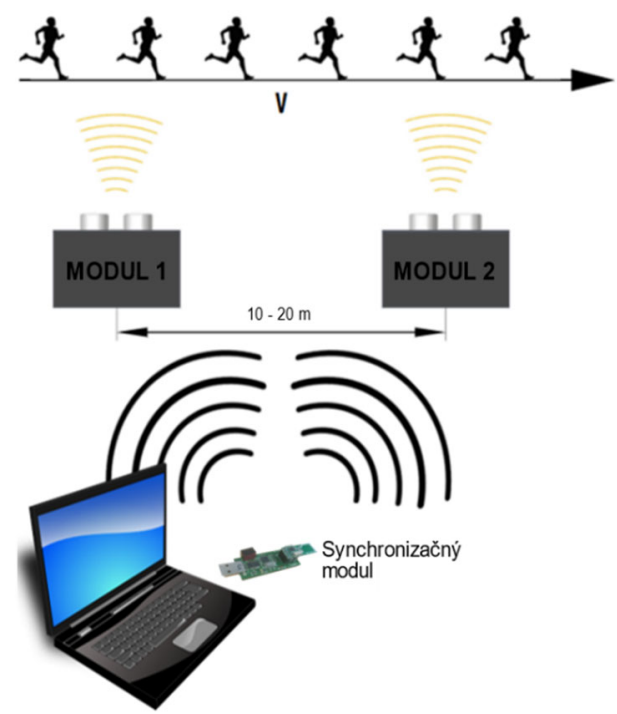

Fig. 1. Measurement method used 
TECHNICAL SCIENCES AND TECHNOLOGIES

Fig. 1 shows the principle of the method used to measure the speed between two points. An important condition in this measurement is the synchronization of the modules, which must be in microseconds for the measured results to be relevant. Therefore, a synchronization module (SM) is used, which communicates via nRF24L01 with measuring modules (MM1 and MM2). As an SM (Fig. 3), we have developed a module that contains an ATmega168 microcontroller. The controller communicates via RS232 with the computer and is also responsible for synchronizing the modules with which it communicates via the mentioned nRF24L01 [4].

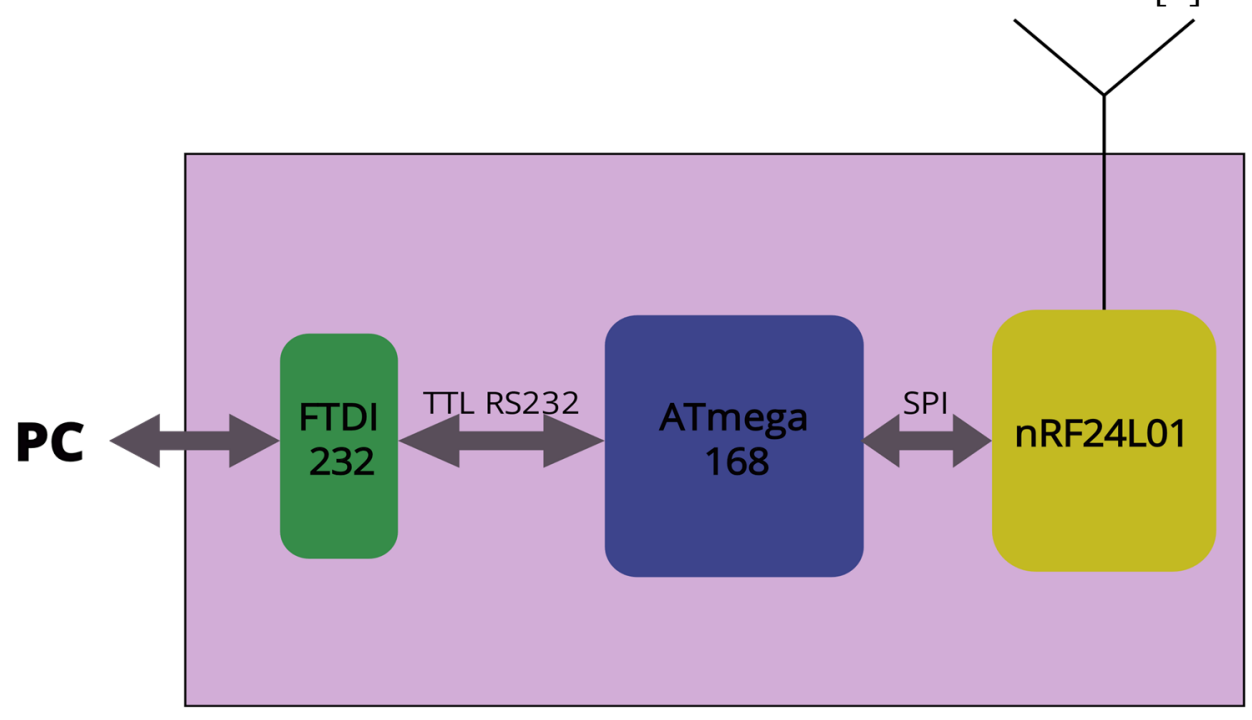

Fig. 2. Synchronization module scheme

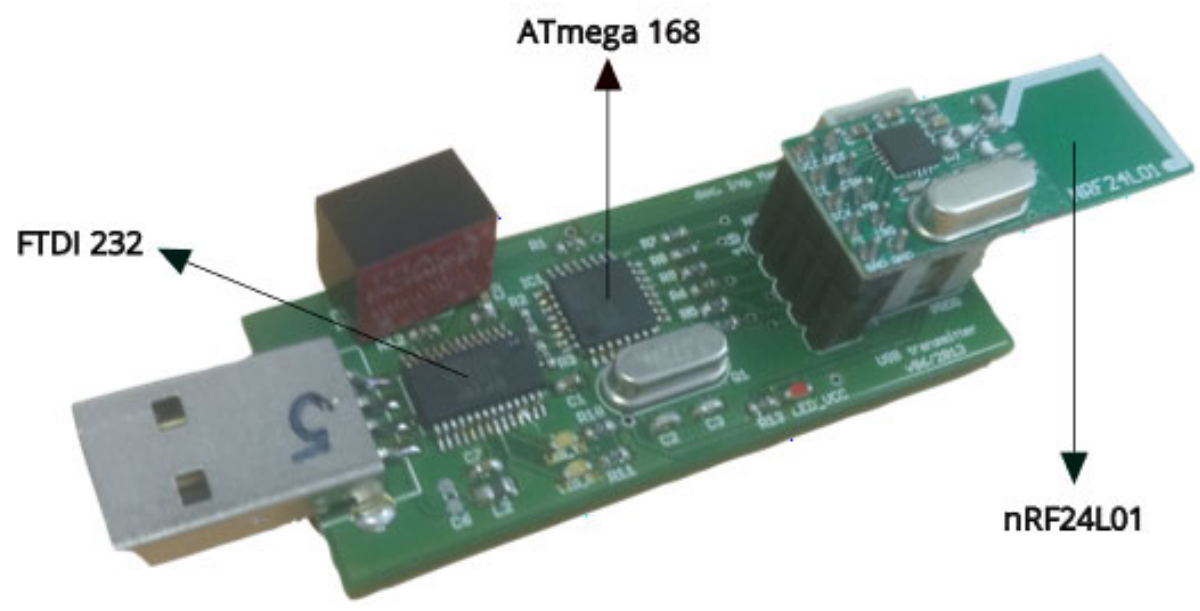

Fig. 3. Synchronization module

Design of measurement modules. The implementation of our speed measurement design took place in several phases. In the first phase, models of modules 1 and 2 were designed and drawn (Fig. 4), in which the individual components are placed. Subsequently, everything was installed in modules and interconnected. In the next phase, algorithms for controlling the entire measurement were designed and implemented. 
TECHNICAL SCIENCES AND TECHNOLOGIES
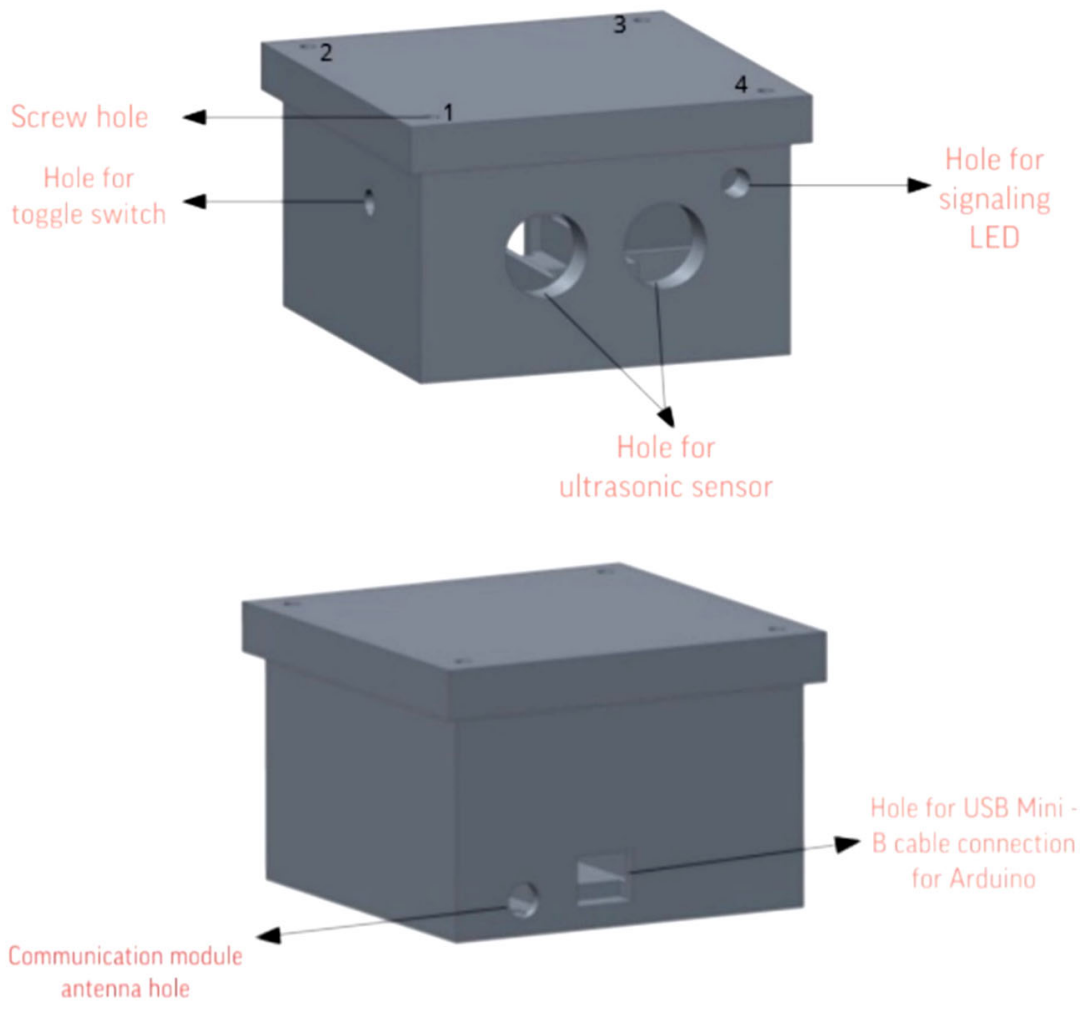

Fig. 4. Design of measuring modules box

Arduino NANO was used as a managing member of MM [2]. The 9V battery was chosen as the power supply component, which is suitable both in terms of capacity and dimensions for this purpose. Furthermore, a control LED was incorporated into the design to monitor the status of the modules. The nRF module is connected to the Arduino via the SPI communication interface and the ultrasonic module HC-SR04 is connected via two IO pins [3]. The wiring diagram is shown in Fig.5.

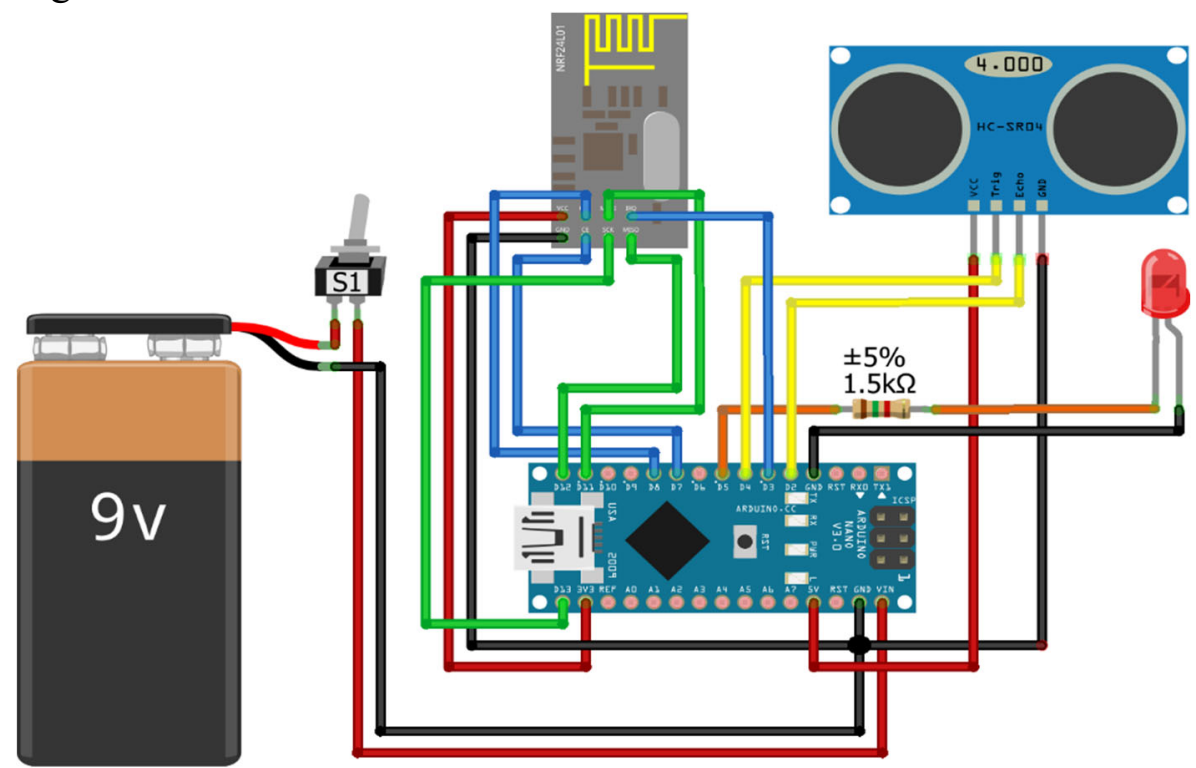

Fig. 5. Wiring diagram of measuring modules 
Proposed measurement algorithms. The design of algorithms had to be based on the principle of operation of the entire measurement system. The time characteristic of the implemented system (Fig. 6) clearly shows the principle of operation, which is as follows:

- SM sends START byte to MM1 and MM2

- Both MMs start the measurement after receiving this apartment

- MM1 sends Tag byte after $15 \mathrm{~ms}$ from the beginning of the measurement

- MM2 sends Tag byte after $20 \mathrm{~ms}$ from the beginning of the measurement

The described schedule of activities is repeated every $33.3 \mathrm{~ms}$, which ensures 30 measurements every second.

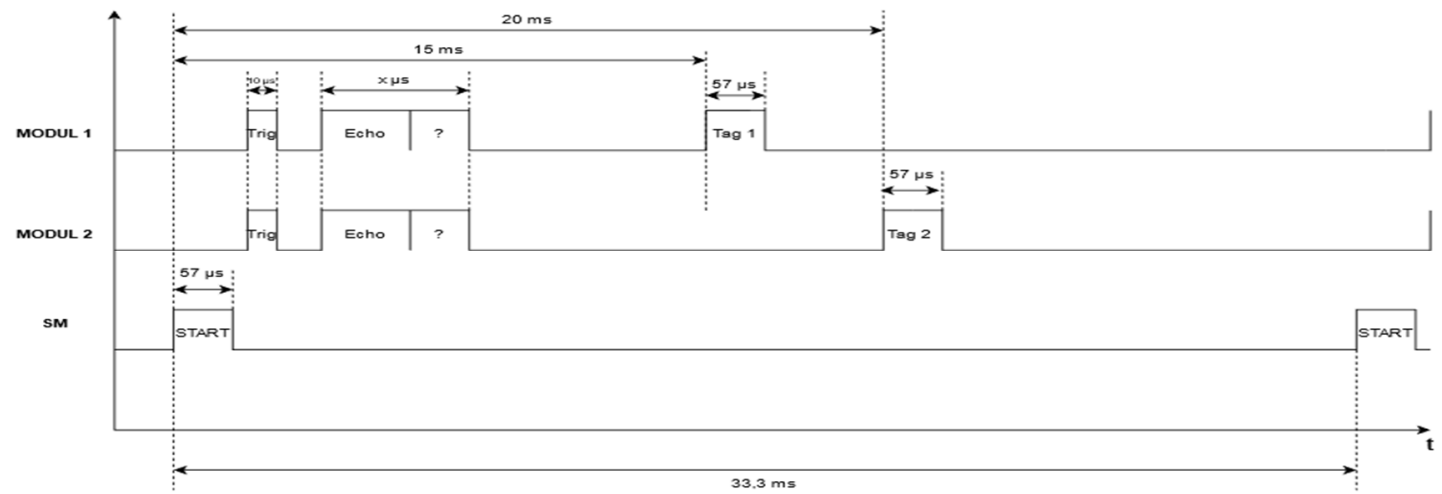

Fig. 6. Time characteristic

Based on this schedule, algorithms were designed for SM (Fig. 7) as well as MM1 and MM2 (Fig. 8).
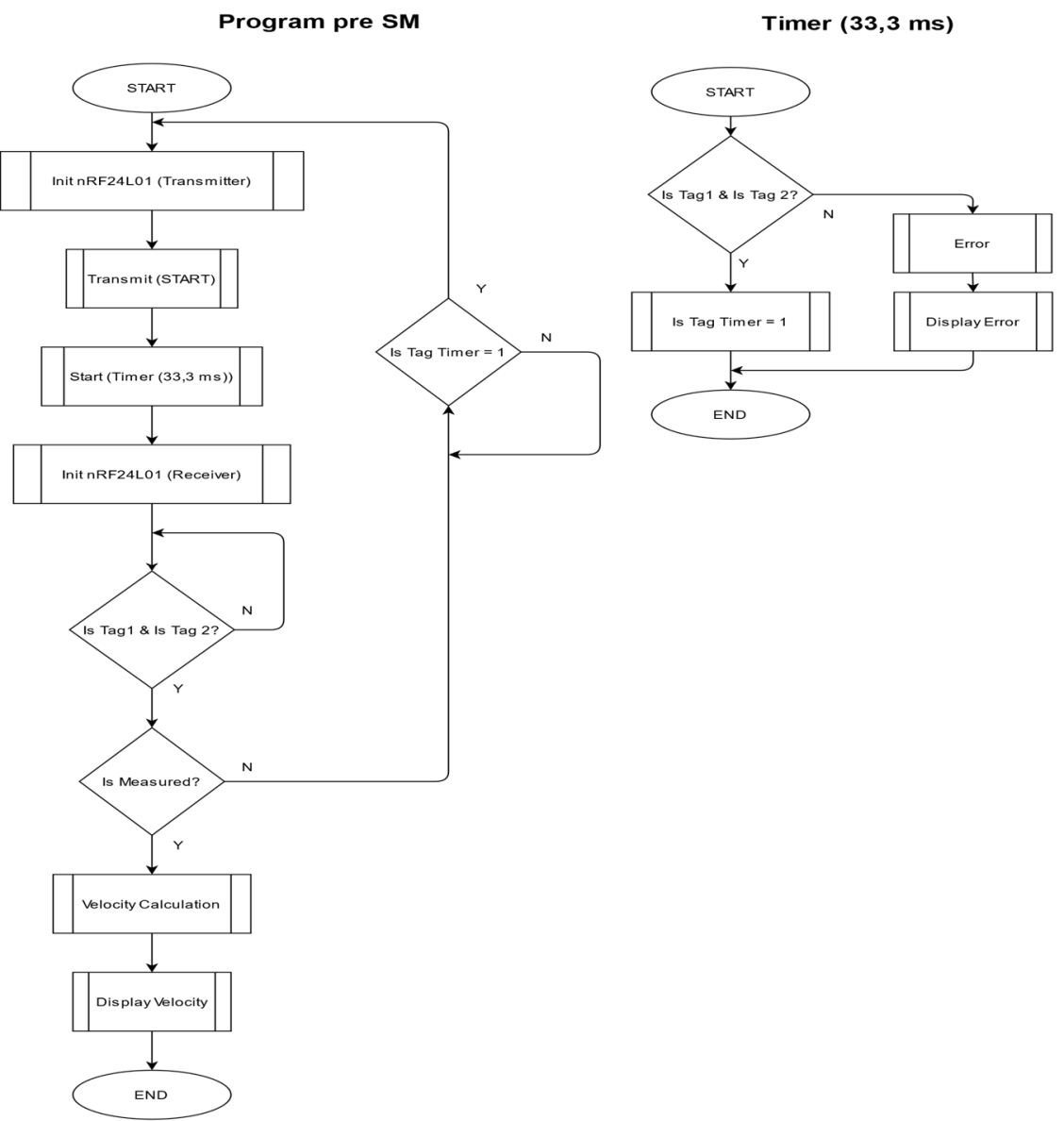

Fig. 7. Algorithm for SM 
The algorithm starts by setting the $\mathrm{nRF}$ in the $\mathrm{SM}$ to the transmission mode (Init_nRF24L01 (Transmitter)) and the subsequent macro Transmit (START). The task of this macro is to send a command that initiates the start of the measurement in MM1 and MM2. After this, the Timer $(33.3 \mathrm{~ms})$ is started, which counts the time in the background and starts the subroutine by $33.3 \mathrm{~ms}$. The goal is to ensure that the measurement is repeated every 33.3 $\mathrm{ms}$ (30 times per second). Immediately after starting the Timer $(33.3 \mathrm{~ms})$, the $\mathrm{nRF}$ in the SM switches to the receive mode (Init_nRF24L01 (Receiver)) so that it can receive data from the MM1 and MM2 modules. Next, it is checked (condition Is Tag 1 \& Is Tag 2?), Whether both ultrasonic sensors measure and send the current measured values (presence of the object in the vicinity of $2 \mathrm{~m}$ ) to the SM. The value of the tags determines whether the object (human) was close to M1 or M2 ( $\operatorname{Tag}=1$ - human was nearby; Tag $=0$ - human was not nearby). Condition Is Tag $1 \&$ Is Tag 2? (more precisely Is Tag 1 (t) = (true or false) \& Tag $2(t)=$ (true or false) ensures the continuation of the program regardless of whether the tags are equal to true or false. If it was not met (either only one would come or no tag would come), it would mean that no data is coming from the MM. At the same time, the feedback treated condition is that the Tags have not yet been measured and are therefore waiting for them to arrive. Next condition Is Measured? represents a state where Tag $2=$ true and Tag 1 have been true sometime in the past (exact notation Is Tag2 $(t)=$ true \& Tag $1(t-n)=$ true). This condition is used to verify whether the measured person passed before MM1 (Tag 1) and at the same time with a certain time delay before MM2 (Tag 2). Only then is the speed measurement successful and can be continued. If the measurement is not successful, the feedback continues to the Is Tag Timer $=$ True condition, which is the Timer $(33.3 \mathrm{~ms})$ count started in the background to 33.3 ms. If the Timer $(33.3 \mathrm{~ms})$ counts to this time, it continues back to the beginning of the program and the whole cycle is executed again. This feedback ensures that the measurements are repeated by both modules every $33.3 \mathrm{~ms}$, ie 30 times per second. If the condition is Is Measured? fulfilled, the Velocity Calculation macro is continued, which is a macro for calculating the speed of the measured person:

$$
\begin{gathered}
v[\mathrm{~km} / \mathrm{h}]=\frac{d m[\mathrm{~m}]}{\Delta T[\mathrm{~ms}] \times 10^{-3}} \times 3,6 \\
\Delta T[\mathrm{~ms}]=t 2-t 1 \\
d m=10 \mathrm{~m}
\end{gathered}
$$

where:

$d_{m}$ is the distance between measuring points (sensors) see. Fig. It can be any in the range from 10 to $20 \mathrm{~m}$.

$t 1$ is the time at which MM1 recorded a change in the measured distance (person).

$t 2$ is the time at which MM2 recorded a change in the measured distance (person).

The last macro of the main program Display Velocity will list the final speed of the measured person in $\mathrm{km} / \mathrm{h}$, or we can add a conversion to $\mathrm{m} / \mathrm{s}(v[\mathrm{~m} / \mathrm{s}]=v[\mathrm{~km} / \mathrm{h}] / 3,6)$. 


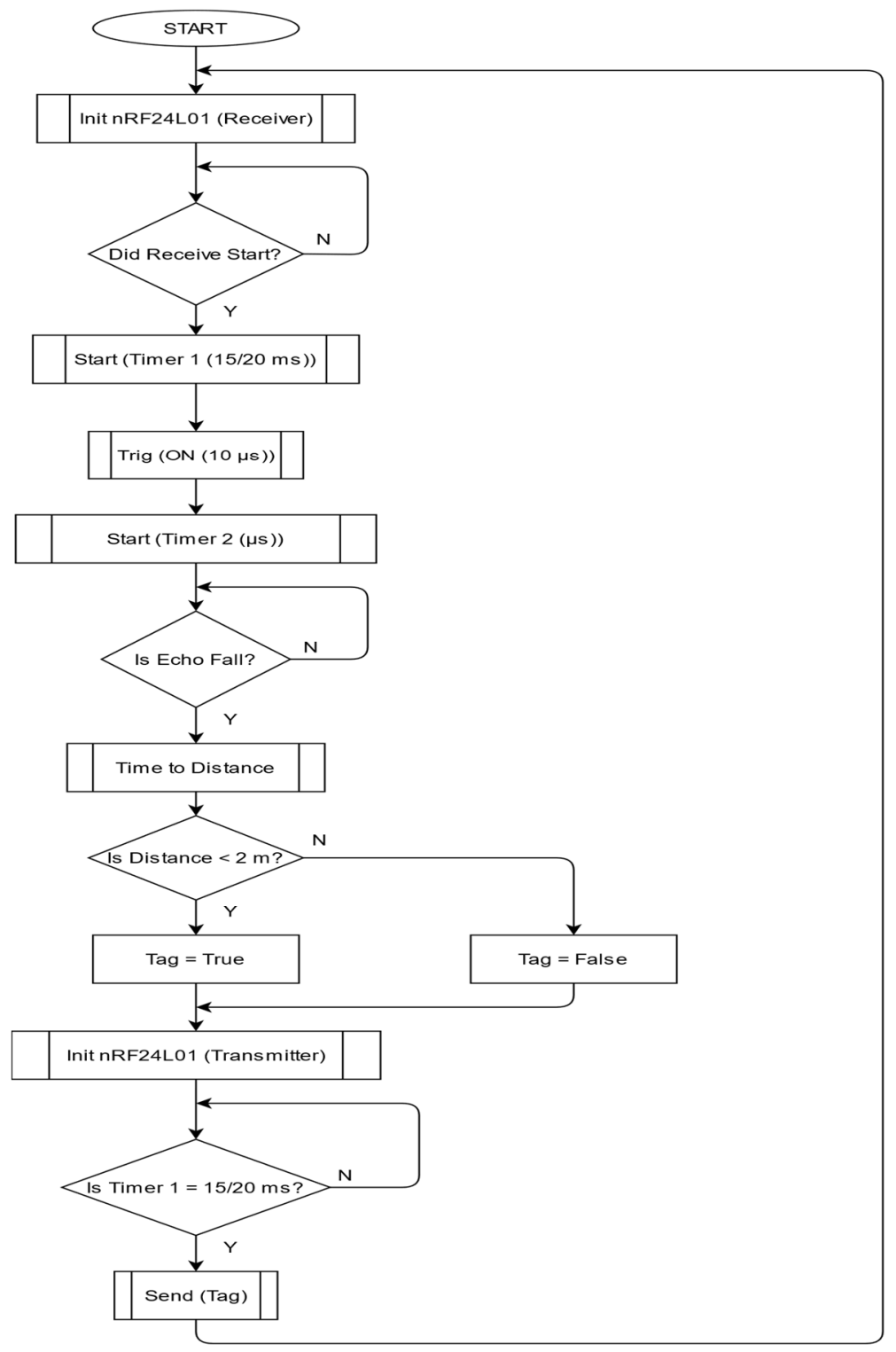

Fig. 8. Algorithm for MM

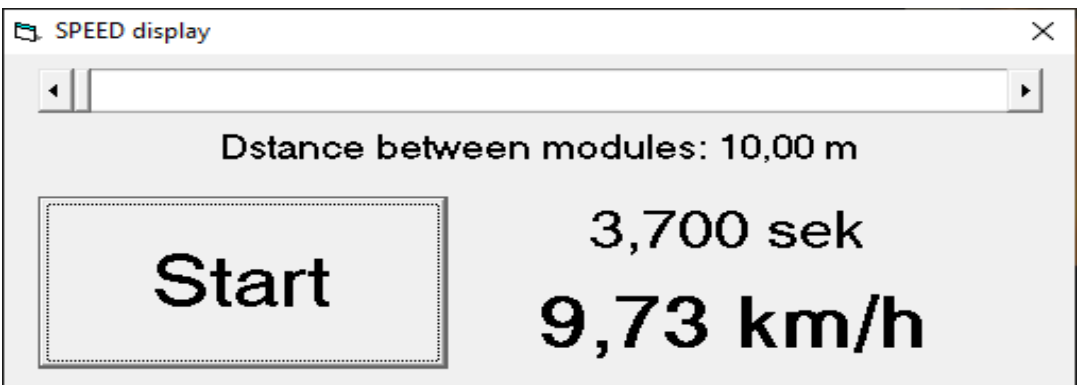

Fig. 9. View the results on computer

Conclusion. We place both modules at a distance of $10-20 \mathrm{~m}$ from each other in places between which the athlete's movement speed is measured. The modules are positioned so that the measured person runs first next to M1 and then next to M2. If a person ran in the opposite direction or if we swapped the individual modules, the speed measurement would not be successful. It is therefore important to know which module is which and based on that to place them correctly. 
The aim was to design and implement speed measurement for sports activities. The described measuring system is perfectly usable in testing the results of training activities. It is possible to use well-targeted testing and training to determine the progress of individuals in speed, or in achieving maximum speed in a short section. Thanks to modules with independent power supply and RF communication, the device is easy to use within a few tens of seconds.

Acknowledgment. This article was created thanks to the support of the KEGA project: 010TUKE-4/2020 Implementation of new knowledge and innovative approaches to the process of teaching robotics in the intentions of Industry 4.

\section{References}

1. Krabáč, K. Zariadenie merania rýchlosti na báze mikrokontroléra a ultrazvukového senzoru pre podporu športového tréningu. Diplomová práca, 2021, Strojnícka fakulta TUKE.

2. Arduino. Dostupné z: https://www.arduino.cc/.

3. Getting Started with the HC=SR04 ultrasonic sensor. Dostupné z: https://create.arduino.cc/projecthub/Isaac100/getting-started-with-the-hc-sr04-ultrasonic-sensor-036380.

4. Arduino Radio Communication (nRF24L01). Dostupné z: https://create.arduino.cc/projecthub/eEdizon/arduino-radio-communication-nrf24101-0fec7a?ref=search\&ref_id=nRF24L01\&offset=5.

Отримано 05.08.2021

UDC 621.941-229.3:621.822.172

\section{Марек Сукоп ${ }^{1}$, Максим Гриців ${ }^{2}$, Карол Кабач}

${ }^{1}$ професор, факультет машинобудування, кафедра виробничих систем та робототехніки

Технічний університет Кошице (Кошице, Словаччина)

E-mail: marek.sukop@,tuke.sk. ORCID: https://orcid.org/0000-0001-7987-3557

${ }^{2}$ аспірант, факультет машинобудування, кафедра виробничих систем та робототехніки

Технічний університет Кошице (Кошице, Словаччина)

E-mail: maksym.grytsiv@tuke.sk. ORCID: https://orcid.org/0000-0002-9412-085X

${ }^{3}$ інж. студент, факультет машинобудування, кафедра виробничих систем та робототехніки

Технічний університет Кошице (Кошице, Словаччина)

E-mail: karol.kabac@student.tuke.sk

\section{ПРОСТЕ ВИМІРЮВАННЯ ШВИДКОСТІ В СПОРТУ НА ОСНОВІ УЛЬТРАЗВУКУ}

У процесі тренування аматорського та професійного спорту необхідний аналіз підвищення результативності. Це можна зробити шляхом об'єктивного вимірювання деяких здібностей спортсмена (необхідних для спорту). Однією з важливих здібностей є максимальна швидкість бігу спортсмена. Ця здатність також потрібна в більшості командних видів спорту.

Початковий намір розробки вимірювального пристрою полягав у досягненні радіолокаиійного вимірювання швидкості рухомих об'єктів у спорті.

На основі первинних випробувань класичних ультразвукових модулів HC-SR04 ми вирішили використати класичний принцип вимірювання швидкості об 'єкта між двома модулями. У иъьму рішенні швидкість переміщення об' єкта між модулями оиінюеться як середня швидкість, досягнута між иими модулями.

Наразі це вимірювання є обмеженим і випробовується лише для вимірювання швидкості бігу спортсменів.

Ми розмішуємо обидва модуля на відстані 10 - 20 м один від одного в місиях, між якими вимірюється швидкість руху спортсмена. Модулі розтамовані так, щзо вимірювана людина бігає спочатку біля M1, а потім поруч із М2. Якби людина бігла в протилежному напрямку або якщо ми поміняли місиями окремі модулі, вимірювання швидкості не було б успішним. Тому важливо знати, який це модуль, і на основі иього правильно їх розмістити.

Метою було розробити та впровадити вимірювання швидкості для спортивних занять.

Описана вимірювальна система чудово підходить для перевірки результатів навчальної діяльності. Можна використовувати иілеспрямоване тестування та навчання, щоб визначити прогрес людей у швидкості або досягнення максимальної швидкості в короткому розділі. Завдяки модулям з незалежним джерелом живлення та радіочастотному зв'язку, пристрій простий у використанні протягом кількох десятків секунд.

Ключові слова: спорт; ультразвук; ультразвуковий датчик; вимірювання швидкості.

Marek, S., Grytsiv, M., Krabáč, K. (2021). Simple speed measurement in sport based on ultrasound. Technical sciences and technologies, $3(25), 213-219$ 